\title{
Karın Ağrılı Hastada Beklenmedik Renkte Kan ve Serum Görünümü
}

\author{
Yalçın GÖLCÜK,' Burcu GÖLCÜK \\ 'İzmir Tepecik Eğitim ve Araştırma Hastanesi, Acil Tıp Kliniği, İzmir; \\ ${ }^{2}$ Çiğli Devlet Hastanesi, İzmir
}

Otuz iki yaşında kadın, acil servisimize bir gündür devam eden, şiddeti gittikçe artan, epigastrik bölgeden başlayıp sırta vuran karın ağrısı, bulantı ve kusma şikayetleriyle başvurdu. Başvuru anında kan basıncı 125/80 mmHg, nabız 71 atım/dakika, solunum sayısı 15 soluk/dakika, oda havasında oksijen satürasyonu $\% 99$ ve vücut sıcaklığı $36.2^{\circ} \mathrm{C}$ olarak kaydedildi. Muayenede bağırsak sesleri normoaktif olan olguda epigastrik hassasiyet vardı, ancak ribaund ve defansı yoktu. Damar yolunu açan ve gerekli testler için kan örneği alan hemşire, hastanın kan rengindeki anormalliği fark
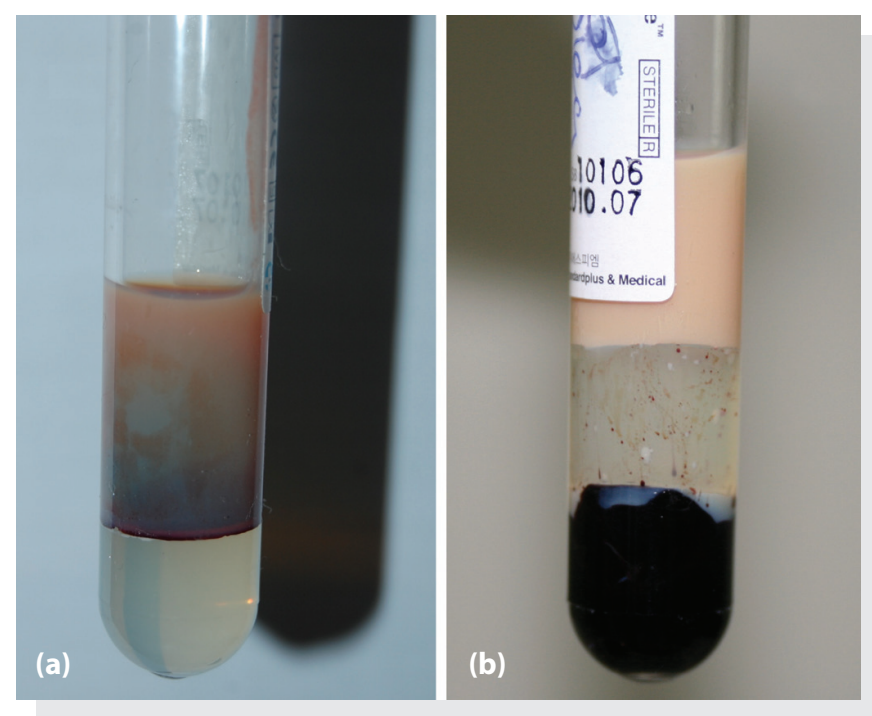

Şekil 1. (a) Santrifüj öncesi bulanık kan örneği. (b) Santrifüj sonrası somon rengindeki serum örneği. ederek durumu doktoruna bildirdi (Şekil 1a). Bulanık renkteki kan örneği biyokimya laboratuvarda 5000 rpm (revolutions per minute) hızında 10 dakika santrifüj edildi. Elde edilen serum örneğinin somon renginde ve süt kıvamında olduğu (Şekil 1b), kıvamından dolayı da biyokimya cihazının bu örneği okuyamadığı bildirildi. Elektrokardiyografisi normal olan, posteroanterior akciğer ve ayakta direkt batın grafisinde anormal bulgu saptanmayan olgunun batın ultrasonografisi ve kontrastlı batın tomografisi (Şekil 2) çekildi.

\section{[TANI IçiN BKZ. s. 32.]}

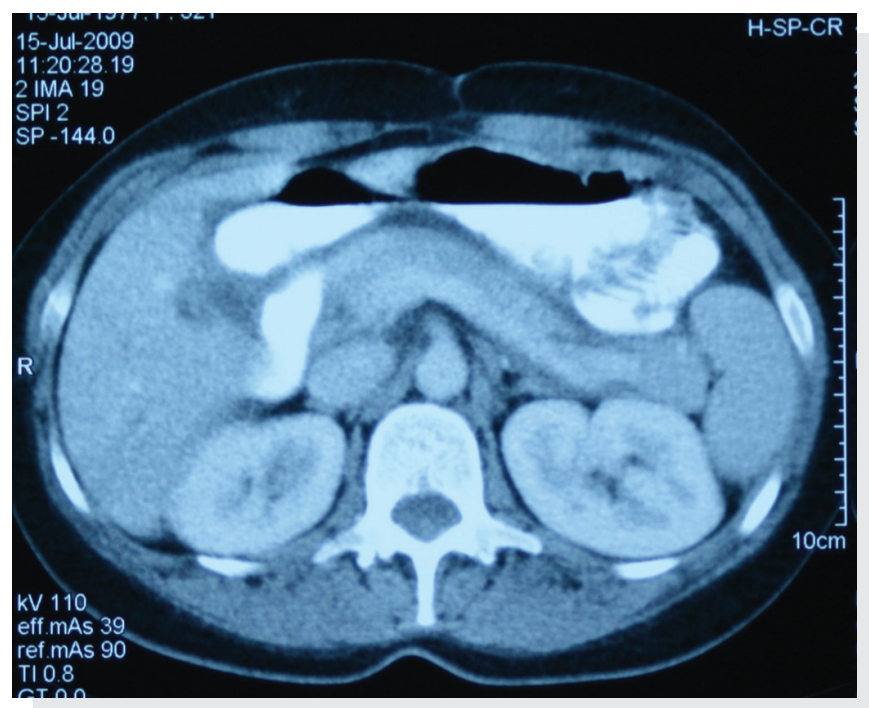

Şekil 2. Kontrastlı bilgisayarlı batın tomografisinde pankreasın ödemli olduğu, pankreas çevresinde ve Morrison poşunda serbest sıvı bulunduğu görülmektedir.

Geliş tarihi (Submitted): 6.10.2010 Kabul tarihi (Accepted): 8.11.2010

İletişim (Correspondence): Dr. Yalçın Gölcük. Tepecik Eğitim ve Araştırma Hastanesi Acil Tıp Kliniği, İzmir, Turkey

e-posta (e-mail): dryalcingolcuk@gmail.com 


\section{TANI: Hipertrigliserideminin Yol Açtığı Akut Pankreatit}

Normalden farklı görünümdeki kan örneği 5000 rpm de 10 dakika santrifüj sonrasında $1 / 10$ oranında dilüe edilerek tekrar çalışıldı. Laboratuvar tetkiklerinde trigliserit $2559 \mathrm{mg} / \mathrm{dL}$ (30-199 mg/dL), total kolesterol $436 \mathrm{mg} / \mathrm{dL}$ (110-199 mg/dL), amilaz $171 \mathrm{U} / \mathrm{L}$ (28-100 U/L), lökosit $8.2 \mathrm{~K} /$ uL (4.0-10.0 K/uL), glukoz 123 mg/dL (74$106 \mathrm{mg} / \mathrm{dL}$ ), kalsiyum $9.1 \mathrm{mg} / \mathrm{dL}$ (8.8-10.6 $\mathrm{mg} / \mathrm{dL}$ ) saptandı. Hastaya klinik, laboratuvar ve görüntüleme sonuçlarına göre hipertrigliserideminin neden olduğu akut pankreatit tanısı kondu.

Akut pankreatitin önemli bir nedeni olan hipertrigliseridemi, tüm akut pankreatit olgularının \%1'inden daha azından sorumludur. ${ }^{[1]}$ Hiperlipidemik hastaların ise \%12-38'inde akut pankreatit gelişebilmektedir. ${ }^{[2]} 1000 \mathrm{mg} / \mathrm{dl}$ üzerindeki trigliserid düzeyleri artmış pankreatit riski ile ilişkilidir. ${ }^{[1]}$ Bu olgularda, pankreatik lipazın trigliseritleri hidrolizi sonucunda ortaya çıkan serbest yağ asitleri, asiner hücrelerde ve kapiller membranlarda hasar meydana getirerek akut pankreatit atağı geliştirebilir. ${ }^{[3]}$ Hipertrigliserideminin yol açtığı akut pankretitlerde beklenenin altında amilaz ve lipaz değerleri görülebilir. ${ }^{[4]}$ Nitekim bizim olgumuzda da kan amilaz değeri eşik değerinin üç katından daha az olarak ölçülmüş, ancak tanı klinik ve radyolojik olarak konulmuştur.

Acil servis hekimleri karın ağrısı ile başvuran, somon rengi ve süt kıvamında serum örneği olan hastalarda hipertrigliserideminin yol açtığı akut pankreatiti ön tanıda düşünmeli, hastalardan kan lipit panelini istemelidir. Hipertrigliserideminin yol açtığı akut pankereatitlerde serum amilaz düzeyi beklenenden düşük olabileceği akılda tutulmalı ve tanı için ileri görüntüleme yöntemlerini kullanmalıdır.

\section{Kaynaklar}

1. Khoury G, Deeba SS. Pancreatitis. emedicine from WebMD (updated: Jun 28, 2010; accessed: Aug 30, 2010). Available at: http://emedicine.medscape.com/ article/181364-overview.

2. Toskes PP. Hyperlipidemic Pancreatitis. Gastroenterol Clin North Am 1990;19:783-91.

3. Pandol SJ, Saluja AK, Imrie CW, et al. Acute pancreatitis: bench to the bedside. Gasrtoenterology 2007;133:1056.e1-1056. e25.

4. Yadav D, Pitchumoni CS. Issues in Hyperlipidemic Pancreatitis. J Clin Gastroenterol 2003;36:54-62. 